\title{
ANALISIS PENGARUH TINGKAT LIKUIDITAS TERHADAP PROFITABILITAS PADA PT. PLN (Persero) KABUPATEN BULUKUMBA
}

\author{
Fahira \\ STIE LPI Makassar \\ Fahira.hira94@gmail.com
}

\begin{abstract}
Abstrak,
Penulisan abstrak maksimal terdiri dari 200 kata berbahasa Indonesia dengan huruf times new roman 11pt. Abstrak setidaknya memuat 3 informasi utama bagi pembaca yaitu latar belakang dan tujuan penelitian, metode yang digunakan, dan ringkasan hasil.
\end{abstract}

Kata Kunci: Maksimum terditi dari 5 kata kunci yang dipisah dengan menggunakan tanda koma (,). Contoh: Mudharabah, Keuangan.

\begin{abstract}
,
The main indicator of this research was how could the companies survive and develop, and the objective effort in increasing profitability. Labored between liquidity on one side and profitability on the other side is not contradictory and can achieve optimal profits without sacrificing company liquidity. This research aimd to determine the effects of liquidity as measuring using the current ratio $(C R)$ on profitability as measuring by Return on Assets (ROA) at PT PLN (Persero) Bulukumba in the period of 2015 to 2017. This research employed quantitative research. Furthermore, the method of data analysis was using financial ratio analysis, simple regression analysis, $t$-test and coefficient of determination. The results of this research that was conducted at PT PLN (Persero) Bulukumba with employed data from 2015 until 2017: (1) The effect of liquidity on profitability showed a negative effect, (2) Current Ratio didn't have a significant effect on Return on Assets.
\end{abstract}

Keywords: Maximum of 5 keywords separated by comma (,). Example: Mudharabah, Finance

\section{PENDAHULUAN / INTRODUCTION}

Era modernisasi dan arus global yang di ikuti perkembangan teknologi yang semakin canggih, bahkan dunia saat ini sudah berada pada era revolusi industru 4.0. Hal tersebut tidak terlepas dari laju pertumbuhan industri, baik industry yang didirikan suasta maupun pemerintah. Pertumbuhan tersebut tentunya berdampak pada semakin banyaknya perusahaanperusahaan yang berdiri khususnya di Indonesia. Setiap perusahaan tersebut tentunnya sangat tergantung pada stabilitas keuangannya dan pastinya memiliki rencana keuangan yang berbeda-beda. Saat ini semua perusahaan harus membuat sebuah laporan yang berkenaan dengan keuangan suatu perusahaan dalam periode tertentu untuk mengetahui perkembangan dan stabilitas keuangannya secara berkala sebagai salah satu barometer untuk melakukan ekspansi, impruvisasi atau perbaikan perusahaan serta untuk mendapatkan informasi berkenaan dengan posisi keuangan dan hasil-hasil yang telah dicapai oleh perusahaan. Menurut Kasmir (2014:7) laporan keuangan adalah "laporan yang menunjukkan kondisi keuangan perusahaan 
pada saat ini atau dalam suatu periode tertentu. Laporan keuangan dibuat per periode, misalnya tiga bulan atau enam bulan untuk kepentingan internalperusahaan. Sementara itu, untuk laporan lebih luas dilakukan satu tahun sekali”.

Data keuangan tersebut akan terasa sangat berguna bagi para pihak yang memiliki kepentingan di dalamnya jika data keuangan untuk dua periode atau lebih dapat diperbandingkan kemudian dilakukan analisa lanjutan untuk memperoleh data yang akan mendukung pengambilan keputusan. Untuk menganalisa dan menilai posisi keuangan serta potensi atau kemajuan kemajuan perusahaan dalam laporan keuangan, faktor yang paling utama untuk mendapatkan perhatian bagi pimpinan perusahaan adalah likuiditas, solvabilitas, rentabilitas, dan profitabilitas perusahaan (Mamduh, M. H., \& Halim, A.2003: 110). Namun pada penelitian ini lebih difokuskan pada pengaruh rasio likuiditas dan rasio profitabilitas perusahaan.

Menurut Kasmir (2012:66) mendefinisikan Analisis Laporan Keuangan adalah "penyusunan laporan keuangan berdasarkan data yang relevan, serta dilakukan dengan prosedur akuntansi dan penilaian yang benar sehingga akan terlibat kondisi keuangan perusahaan yang sesungguhnya". Analisis laporan keuangan bertujuan untuk mengetahui apakah keadaan keuangan, hasil usaha kemajuan keuangan perusahaan memuaskan atau tidak memuaskan. Analisis dilakukan dengan mengukur hubungan antar unsur-unsur laporan keuangan dan bagaimana perubahan unsur-unsur itu dari tahun ke tahun dan untuk mengetahui arah perkembangannya.

Suatu perusahaan dikatakan berhasil dalam kegiatan usahanya apabila secara terus menerus mampu memenuhi kewajiban finansial jangka pendeknya yang harus segera dibayar dan mendapatkan laba yang merupakan syarat mutlak dalam menjamin kelangsungan hidup suatu perusahaan. Dengan kata lain, perusahaan harus mempertimbangkan aspek likuiditas dan aspek profitabilitasnya agar usahanya dapat berhasil. Likuiditas menunjukkan kemampuan suatu perusahaan untuk memenuhi kewajiban keuangannya yang harus segera dipenuhi atau saat ditagih, sedangkan profitabilitas mengukur kemampuan para eksekutif perusahaan dalam menciptakan tingkat keuntungan baik dalam bentuk laba perusahaan maupun nilai ekonomis atas penjualan, aset bersih perusahaan maupun modal sendiri. Rasio likuiditas dapat diukur dengan menggunakan beberapa rasio seperti current ratio $(\mathrm{CR})$, quick ratio $(\mathrm{QR})$ dan cash ratio sedangkan Rasio profitabilitas dapat diukur menggunakan beberapa rasio seperti profit margin, ROA dan ROE (Raharjaputra, H. S. 2009: 194 \& 205)

PT. PLN (Persero) Area Bulukumba mempunyai misi untuk meningkatkan kualitas kehidupan masyarakat dan mendorong kegiatan ekonomi agar tercipta kehidupan yang lebih baik. Maka dalam menjalankan operasional usahanya memerlukan dana yang cukup banyak dimana dalam penggunaannya serta pengelolaannya diperlukan pelaporan data yang akurat. Berdasarkan uraian permasalahan diatas, maka perlu untuk melakukan analisis Pengaruh Likuiditas Terhadap Profitabilitas Pada PT. PLN (Persero) Kabupaten Bulukumba

\section{TINJAUAN TEORITIK / LITERATURE REVIEW}

\section{Pengertian dan Jenis-Jenis Rasio Likuiditas}

Alex S. (1983: 40) Nitisemito mengemukakan likuiditas adalah kemampuan suatu perusahaan untuk memenuhi seluruh kewajiban yang segera harus dibayar. Sedangkan Kasmir dan Jakfar (2012: 125) juga mengemukakan Rasio Likuiditas merupakan rasio yang digunakan dalam mengukur seberapa likuid suatu perusahaan. Caranya adalah dengan membandingkan seluruh komponen yang ada di aktiva lancar dengan komponen di passiva lancar (utang jangka pendek). Sementara Atmajaya (2003:416) menyatakan rasio likuiditas, yang menunjukkan 
kemampuan perusahaan untuk memenuhi kewajiban finansial yang berjangka pendek tepat pada waktunya.

Dari uraian dan definisi tersebut, maka dapat disimpulkan bahwa pengertian dari rasio likuiditas adalah alat yang digunakan untuk menghitung kemampuan perusahaan untuk kewajiban-kewajiban jangka pendeknya, dengan cara membandingkan aktiva lancar perusahaan dengan kewajiban lancar perusahaan yang tercantum pada neraca perusahaan pada periode tertentu. Likuiditas juga merupakan indikator untuk melihat terjadinya alat-alat likuid yang meliputi: kas, piutang, persediaan dan surat-surat berharga didalam perusahaan dalam menjamin tersedianya dana dalam membiayai operasional perusahaan sehari-hari.

Tingkat likuiditas sangat memengaruhi keberhasilan dan kelancaran perusahaan dalam menjalankan aktivitasnya atau dengan kata lain tingkat likuiditas sangat menentukan dalam rangka menjaga dan menjamin eksistensi perusahaan. Oleh karena itu tingkat likuiditas tertentu suatu perusahaan harus dapat dipertahankan untuk menjamin kelancaran pengolahan perusahaan.

Namun di sisi lain tingkat likuiditas yang tinggi (besar), dapat diartikan adanya saldo kas yang menganggur, tingkat persediaan yang berlebihan dibandingkan dengan kebutuhan yang ada, serta kebijakan kredit yang keliru yang mengakibatkan piutang usaha menjadi berlebihan. Hal-hal ini menunjukkan praktik-praktik manajemen yang kurang baik.

Tingkat likuiditas dapat diukur dengan menggunakan beberapa rasio, antara lain sebagai berikut (Kasmir dan Jakfar 2012: 125-128):

1. Rasio lancar (Current Ratio)

Current ratio merupakan rasio lancar mengukur kemampuan perusahaan membayar kewajiban jangka pendek atau utang yang segera jatuh tempo pada saat ditagih. Dengan kata lain seberapa banyak aktiva lancar yang tersedia untuk menutupi kewajiban jangka pendek yang segera jatuh tempo. Rasio lancar dapat pula dikatakan sebagai bentuk untuk mengukur tingkat keamanan (margin of safety).

Dalam praktiknya, rasio lancar 200\% terkadang sudah dianggap ukuran yang memuaskan bagi perusahaan, sekalipun ukuran yang terpenting adalah rata-rata industri untuk perusahaan yang sejenis.

Rumus untuk mencari current ratio yang dapat digunakan, sebagai berikut:

$$
\text { Current Ratio }=\frac{\text { aktiva lancar }}{\text { hutang lancar }} \times 100 \%
$$

2. Rasio cepat (Quick Ratio)

Quick ratio merupakan rasio uji cepat yang menunjukkan kemampuan perusahaan membayar kewajiban jangka pendek dengan aktiva lancar tanpa memperhitungkan persediaan. Hal ini disebabkan persediaan memerlukan waktu relatif lebih lama untuk diuangkan dibandingkan dengan aset lain, dengan kata lain, quick ratio diukur dari total aktiva lancar kemudian dikurangi dengan persediaan termasuk biaya yang dibayar dimuka dan dibandingkan dengan seluruh utang lancar.

Rumus yang dapat digunakan untuk mencari quick ratio sebagai berikut:

$$
\text { Quick Ratio }=\frac{\text { aktivalancar }- \text { Persediaan }}{\text { hutanglancar }} \mathrm{X}
$$




\section{Rasio kas (Cash ratio)}

Cash ratio merupakan alat untuk mengukur seberapa besar uang kas yang tersedia untuk membayar utang. Hal ini dapat ditunjukkan dari tersedianya dana kas atau yang setara kas seperti rekening giro. Rasio ini menunjukkan kemampuan sesungguhnya bagi perusahaan untuk membayar utang-utang jangka pendeknya.

Rumus untuk mencari cash ratio dapat digunakan sebagai berikut:

Cash Ratio $=\frac{\text { kas }+ \text { bank }}{\text { hutang lancar }} \times 100 \%$

\section{Pengertian dan Jenis-Jenis Rasio Profitabilitas}

J. Fred Weston (1997: 225) mengemukakan bahwa rasio profitabilitas adalah rasio yang mengukur efektivitas manajemen yang ditunjukkan oleh laba yang dihasilkan dari penjualan dan investasi perusahaan. Napa J. Awat (1999:391) juga mengemukakan rasio profitabilitas berusaha mengukur kemampuan menghasilkan laba, baik dengan menggunakan seluruh aktiva yang ada maupun dengan menggunakan modal sendiri. Sedangkan Alex S. Nitisemito (1983:51) mengemukakan bahwa profitabilitas adalah kemampuan perusahaan untuk menghasilkan keuntungan dibandingkan dengan modal yang digunakan dan dinyatakan dalam persentase. 26

Dari uraian dan beberapa definisi di atas dapat disimpulkan bahwa pengertian rasio profitabilitas adalah alat yang digunakan untuk mengukur kemampuan perusahaan dalam menghasilkan keuntungan, sebagai hasil dari penggunaan sejumlah modal, aktiva dan penjualan, yang dinyatakan dalam persentase $(\%)$.

Cara untuk menilai profitabilitas suatu perusahaan bermacam-macam. Hal ini tergantung kebutuhan pihak yang berkepentingan terhadap perusahaan, Mengingat rasio ini sangat dibutuhkan oleh pihak investor jangka panjang, misalnya pemegang saham dan calon pemegang saham, untuk melihat keuntungan yang benar-benar akan diterima dalam bentuk dividen. Terlebih lagi bagi pihak manajemen perusahaan, rasio ini merupakan tolak ukur efektivitas manajemen dalam menggunakan total aktiva seperti yang tercatat dalam neraca, sehubungan dengan tingkat keuntungan yang diperoleh perusahaan pada periode tertentu.

Rasio ini terdiri dari (Kasmir dan Jakfar, 2012: 141-143):

1. Profit margin (profit margin on sales)

Rasio ini diukur antara profit margin dan penjualan, dan di ukur dalam persentase. Rumus untuk mencari profit margin sebagai berikut:

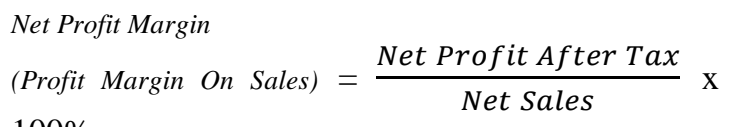

\section{Return on Assets (ROA)}

Return on Assets merupakan rasio yang menunjukkan hasil (return) atas jumlah aktiva yang digunakan dalam perusahaan atau suatu ukuran tentang efisiensi manajemen. Rasio ini menunjukkan hasi dari seluruh aktiva yang dikendalikannya dengan mengabaikan sumber pendanaan dan biasanya rasio ini diukur dengan persentase. Rasio ini menunjukkan produktivitas dari seluruh dana perusahaan baik modal pinjaman maupun modal sendiri. Semakin kecil (rendah) rasio ini, semakin tidak baik, demikian pula sebaliknya. Artinya, rasio ini digunakan untuk mengukur efektivitas dari keseluruhan operasi perusahaan.

Rumus untuk mencari return on Assets dapat digunakan sebagai berikut: 


$$
\text { Returnon Assets }=\frac{\text { Net Profit After Tax }}{\text { Total Assets }}
$$

\section{Return on Equity (ROE)}

Return on Equity atau rentabilitas modal sendiri merupakan rasio untuk mengukur laba bersih sesudah pajak dengan modal sendiri. Semakin tinggi rasio ini semakin baik. Artinya, posisi pemilik perusahaan semakin kuat, demikian pula sebaliknya.

Rumus untuk mencari Return on Equity dapat digunakan sebagai berikut:

Return on Equity $=\frac{\text { Net Profit After } \text { Tax }}{\text { Equity }}$

\section{METODE PENELITIAN / METHODS}

\section{Jenis Penelitian}

Penelitian ini tergolong Kuantitatif (Sugiyono, 2017), yaitu data yang diperoleh dari PT. PLN (Persero) ULP Tanete dalam bentuk laporan keuangan.

\section{Analisis Pengumpula Data}

Untuk mengelolah data yang telah dikumpulkan dari hasil penelitian penulis menggunakan analisis kinerja keuangan dengan teknik analisis rasio keuangan, yaitu analisis rasio likuiditas dan rasio profitabilitas.

1. Rasio Likuiditas

Pada penelitian ini rasio likuiditas diukur dengan menggunakan Current Rastio (CR) dengan rumusan sebagai berikut:

$$
\text { Current Ratio }=\frac{\text { aktivalancar }}{\text { hutanalancar }} \times 100 \%
$$

2. Rasio Profitabilitas

Pada penelitian ini rasio profitabilitas diukur dengan menggunakan Return of Asset (ROA) dengan rumusan sebagai berikut:

$$
\text { Return On assets }=\frac{\text { net } \text { profit after tax }}{\text { total assets }} \mathrm{x}
$$

\section{Analisis Regresi Sederhana}

Analisis regresi sederhana digunakan untuk mengetahui pengaruh antara variabel indenpenden terhadap variabel dependen. Adapun formula dari regresi sederhana adalah sebagai berikut:

$$
Y=a+b X+e
$$

Keterangan:

$\mathrm{Y}=$ variabel dependen 


$$
\begin{aligned}
& \mathrm{a}=\text { konstanta } \\
& \mathrm{b}=\text { koefisien regresi } \\
& \mathrm{X}=\text { variabel independen } \\
& \mathrm{e}=\text { Standar error }
\end{aligned}
$$

\section{Uji t (Parsial)}

Uji t digunakan untuk mengetahui apakah dalam model regresi variabel independen (X) secara parsial berpengaruh signifikan terhadap variabel dependen (Y). Adapun langkah-langkah pengujian adalah sebagai berikut:

a. Menentukan hipotesis

Ho: $\beta=0$ Likuiditas tidak berpengaruh signifikan terhadap profitabilitas.

Ha: $\beta \neq 0$ Likuiditas berpengaruh signifikan terhadap profitabilitas.

b. Menentukan tingkat signifikansi menggunakan $\alpha=0,05$

c. Kriteria pengujian

Ho: diterima jika $-\mathrm{t}$ tabel $\leq \mathrm{t}$ hitung $\leq \mathrm{t}$ table

Ho: ditolak $-\mathrm{t}$ hitung $<\mathrm{t}$ tabel atau $\mathrm{t}$ hitung $>\mathrm{t}$ table

\section{Koefisien determinasi (R2)}

Tujuan menghitung koefisien determinasi adalah untuk mengetahui ketangguhan modal yang digunakan sebagai prediktor.

Nilai R2 mempunyai interval antara 0 sampai $1(0 \leq \mathrm{R} 2 \leq 1)$. Semakin besar nilai R2 (mendekati 1), semakin baik hasil untuk modal regresi tersebut. Dan semakin mendekati 0, maka variabel independen secara keseluruhan tidak dapat menjelaskan variabel dependen

\section{HASIL DAN PEMBAHASAN / DISCUSSION}

\section{Analisis Rasio Likuiditas}

Untuk menganalisis tingkat likuiditas PT PLN (Persero) Bulukumba, digunakan laporan keuangan yaitu neraca dalam 3 (tiga) tahun yaitu tahun 2015 sampai dengan tahun 2017, sebagai sumber data (laporan keuangan PT PLN (Persero) Bulukumba). Berdasarkan data-data tersebut, current ratio digunakan sebagai alat analisis. Adapun formula dari current ratio adalah sebagai berikut:

Current Ratio $=\frac{\text { aktivalancar }}{\text { hutang lancar }} \times 100 \%$

Current Ratio, rasio ini menunjukkan kemampuan suatu perusahaan untuk dapat membayar hutangnya yang segera jatuh tempo, dengan jaminan aktiva lancar.

Perhitungan tingkat likuiditas PT PLN (Persero) Bulukumba selama 3 (Tiga) tahun (20152017) adalah sebagai berikut:

a. Tahun 2015

$$
\text { Current Ratio }=\frac{518,715,038,425}{599,735,959,583} \times 100 \%=86.49 \%
$$

b. Tahun 2016

$$
\text { Current Ratio }=\frac{605,049,019,444}{1,009,110,227,371} \times 100 \%=59.95 \%
$$

c. Tahun 2017

$$
\text { Current Ratio }=\frac{639,164,177,676}{1,095,816,577,095} \times 100 \%=58.32 \%
$$

Untuk lebih memudahkan dalam menganalisis tingkat likuiditas PT PLN (Persero) Bulukumba berikut ini disajikan Current Ratio dalam bentuk tabel beserta tingkat perubahannya. 
Tabel 1

Perhitungan Rasio Likuiditas PT (Persero) Bulukumba

Tahun 2015-2017

\begin{tabular}{|c|c|c|c|c|c|c|}
\hline Tahun & \multicolumn{2}{|c|}{$\begin{array}{c}\text { Aktiva } \\
\text { Lancar }\end{array}$} & \multicolumn{2}{c|}{$\begin{array}{c}\text { Hutang } \\
\text { Lancar }\end{array}$} & \multicolumn{2}{c|}{$\begin{array}{c}\text { Current } \\
\text { Ratio }\end{array}$} \\
\cline { 2 - 7 } & $\begin{array}{c}\text { A L } \\
\text { (Jutaan } \\
\text { Rp) }\end{array}$ & $\begin{array}{c}\boldsymbol{\Delta} \\
\text { (Jutaan } \\
\text { Rp) }\end{array}$ & $\begin{array}{c}\text { H L } \\
\text { (Jutaan Rp) }\end{array}$ & $\begin{array}{c}\Delta \\
\text { (Jutaan } \\
\text { Rp) }\end{array}$ & $\begin{array}{c}\text { Current } \\
\text { Ratio } \\
(\%)\end{array}$ & $\begin{array}{c}\Delta \\
(\%)\end{array}$ \\
\hline 2015 & 518.715 .038 .425 & - & 599.735 .959 .583 & - & 86,49 & - \\
\hline 2016 & 605.049 .019 .444 & 86.333 .981 .019 & 1.009 .110 .227 .371 & 409.374 .267 .788 & 59,95 & $(26,54)$ \\
\hline 2017 & 639.164 .177 .676 & 34.115 .158 .232 & 1.095 .816 .577 .095 & 86.706 .349 .724 & 58,32 & $(1,63)$ \\
\hline
\end{tabular}

Keterangan:

$\Delta=$ Perubahan nilai

()$=$ Menurun

Sumber: PT. PLN (Persero) Bulukumba

Berdasarkan hasil perhitungan di atas dapat ditunjukkan bahwa perkembangan tingkat likuiditas (current ratio) PT. PLN (Persero) Bulukumba 3 (tiga) tahun terakhir mengalami penurunan diketahui rasio likuiditas current ratio tahun 2015 sebesar 86,49 dan tahun 2016 sebesar 59,95 dan pada tahun 2017 sebesar 58,32. Penurunan ini dikarenakan aktiva lancar lebih rendah dan lebih kecil nilainya dibandingkan dengan hutang lancar. Hal tersebut dapat terjadi karena pada laporan keuangan terdapat besaran biaya yang masih harus dibayarkan yang terus mengalami peningkatan, pembayaran hutang usaha, hutang pajak, denda-denda dan lain sebagainya, sehingga aktiva lancar yang dimiliki belum mampu melunasi kewajiban jangka pendeknya (hutang lancar).

Analisis Rasio Profitabilitas.

Dalam menghitung tingkat Profitabilitas PT. PLN (Persero) Bulukumba, seperti analisis likuiditas diatas digunakan laporan keuangan yaitu neraca dan laporan laba rugi 3 (tiga) tahun terakhir, yaitu dari tahun 2015 sampai tahun 2017, sebagai sumber data (laporan keuangan PT. PLN (Persero) Bulukumba).

Berdasarkan data-data tersebut digunakan Return on Assets (ROA) sebagai alat analisis. Rasio ini digunakan untuk mengukur keefektifan manajemen dalam menghasilkan laba dengan aset yang tersedia. Adapun formulasi dari $R O A$ ini adalah sebagai berikut:

$$
\text { Return On Assets }=\frac{\text { Net Profit After Tax }}{\text { Total Assets }} \times 100 \%
$$

Perhitungan tingkat profitabilitas PT PLN (Persero) Bulukumba selama 3 (tiga) tahun (2015-2017) adalah sebagai berikut:

a. Tahun 2015

b. Tahun 2016

$$
R O A=\frac{1.074 \cdot 327 \cdot 866.295}{19.534 \cdot 808 \cdot 103.014} \times 100 \%=5,50 \%
$$

$$
R O A=\frac{1.307 .860 .014 .368}{21.713 .911 .920 .342} \times 100 \%=6,02 \%
$$

c. Tahun 2017

$$
R O A=\frac{1.218 .838 .202 .822}{22.383 .882 .755 .850} \times 100 \%=5,46 \%
$$


Untuk lebih memudahkan dalam menganalisa tingkat profitabilitas PT PLN (Persero) Bulukumba, berikut ini penulis menyajikan ROA dalam bentuk tabel beserta tingkat perubahannya.

Tabel 2

Perhitungan Rasio Profitabilitas PT PLN (Persero) Bulukumba

Tahun 2015-2017

\begin{tabular}{|c|c|c|c|c|c|c|}
\hline \multirow[t]{2}{*}{ Tahun } & \multicolumn{2}{|l|}{$\begin{array}{l}\text { Net Pofit } \\
\text { After Tax }\end{array}$} & \multicolumn{2}{|l|}{ Total Assets } & \multicolumn{2}{|l|}{$R O A$} \\
\hline & $\begin{array}{c}\text { NPAT } \\
\text { (Jutaan Rp) }\end{array}$ & $\begin{array}{c}\Delta \\
\text { (Jutaan Rp) }\end{array}$ & $\begin{array}{c}\text { Total Assets } \\
\text { (Jutaan Rp) }\end{array}$ & $\begin{array}{c}\Delta \\
\text { (Jutaan Rp) }\end{array}$ & $\begin{array}{l}R O A \\
(\%)\end{array}$ & $\underset{(\%)}{\Delta}$ \\
\hline 2015 & 1.074 .327 .866 .295 & - & 19.534 .808 .103 .014 & - & 5,50 & - \\
\hline 2016 & 1.307 .860 .014 .368 & 233.532 .148 .073 & 21.713.911.920.342 & 2.179 .103 .817 .328 & 6,02 & 0,52 \\
\hline 2017 & 1.218 .838 .202 .822 & (89.021.811.546) & 22.383 .882 .755 .850 & 669.970.835.508 & 5,46 & $(0,56)$ \\
\hline
\end{tabular}

Keterangan:

$\Delta=$ Perubahan nilai

( ) = Menurun

Sumber: PT PLN (Persero) Bulukumba

Berdasarkan hasil perhitungan di atas, dapat ditunjukkan bahwa perkembangan tingkat profitabilitas (ROA) PT PLN (Persero) Bulukumba mengalami fluktuasi pada 3 (tiga) tahun terakhir yaitu pada tahun 2015-2017. Berdasarkan laporan keuangan, dapat di lihat bahwa pada tahun 2016 mengalami kenaikan, kemudian pada tahun 2017 kembali mengalami penurunan. Nilai tertinggi $R O A$ sebesar $6,02 \%$ yaitu pada tahun 2016, sedangkan nilai terendah yaitu pada tahun 2017 sebesar 5,46\%. Hal ini dikarenakan laba bersih setelah pajak yang di peroleh PT PLN (Persero) Bulukumba mines (rugi) sebesar 89.021.811.546 sehingga turun dari angka 1.307.860.014.368 di tahun 1016 menjadi 1.218 .838 .202 .822 pada tahun berikutnya yaitu tahun 2017. Hal ini disebabkan karena beban usaha meningkat lebih besar.

Selain itu total aktiva yang dimiliki PT PLN (Persero) Bulukumba juga tinggi, aktiva lancar yang berlebihan justru menunjukkan adanya dana yang tidak produktif dan terkesan perusahaan melepaskan untuk memperoleh keuntungan. Idealnya, modal kerja perusahaan seharusnya tersedia dalam jumlah yang cukup untuk membiayai berbagai kegiatan perusahaan, yang berarti tidak terdapat kekurangan modal dan tidak terdapat sumber daya yang menganggur. Dengan demikian kemampuan perusahaan menghasilkan laba atas aktiva yang dimiliki menjadi maksimum.

\section{Uji Statistik}

\section{Analisis Regresi Sederhana}

Analisis regresi sederhana merupakan analisis terhadap variabel baik dependen maupun indepen mempunyai skala numerik. Oleh karena itu, analisis ini sering digunakan untuk melihat hubungan antara variabel baik positif maupun negatif digunakan untuk memprediksi nilai dari variabel dependen apabila varibel independen mengalami kenaikan atau penurunan. berikut:

Analisis ini dapat dihitung menggunakan program SPSS yang didapatkan hasil sebagai

\section{Tabel 3 \\ Model Regresi \\ Coefficients $^{\mathrm{a}}$}

Al-Kharaj: Journal of Islamic Economic and Business Vol. 1 No. 1, Juni 2019 


\begin{tabular}{|c|c|c|c|c|c|c|}
\hline \multirow{2}{*}{\multicolumn{2}{|c|}{ Model }} & \multicolumn{2}{|c|}{ Unstandardized Coefficients } & \multirow{2}{*}{$\begin{array}{c}\begin{array}{c}\text { Standardized } \\
\text { Coefficients }\end{array} \\
\text { Beta }\end{array}$} & \multirow[t]{2}{*}{$\mathrm{T}$} & \multirow[t]{2}{*}{ Sig. } \\
\hline & & $\mathrm{B}$ & Std. Error & & & \\
\hline \multirow{2}{*}{1} & (Constant) & 6,195 & 1,260 & & 4,918 & , 128 \\
\hline & Likuiditas &,- 008 & 018 &,- 397 &,- 432 & ,740 \\
\hline
\end{tabular}

a. Dependent Variable: Profitabilitas

\section{Sumber: data diolah (output program SPSS 20)}

Dari data di atas maka pada regresi sederhana dapat dituliskan, sebagai berikut:

$\mathrm{Y}=\mathrm{a}+\mathrm{bX}$

$Y=6,195+-0,008 X$

Keterangan:

Persamaan regresi di atas dapat dijelaskan sebagai berikut:

a. Konstanta sebesar 6,195 artinya apabila variabel X (Likuiditas) nilainya 0, maka nilai profitabilitasnya adalah 6,195 .

b. Koefisien regresi variabel $\mathrm{X}$ sebesar $-0,008$ menyatakan bahwa setiap penambahan $1 \%$ nilai likuiditas, maka nilai partisipasi tambahan sebesar -0,008, artinya koefisien regresi tersebut bernilai negatif sehingga dapat dikatakan bahwa arah pengaruh variabel X (Likuiditas) terhadap variabel Y (Profitabilitas) adalah negatif.

\section{Uji t (Parsial)}

Uji parsial ini bertujuan untuk mengetahui besarnya pengaruh masing-masing variabel independen secara individual (parsial) terhadap variabel dependen. Hasil uji parsial ini dapat dilihat pada tabel coefficients ${ }^{a}$. Nilai hitung dari uji-t dapat dilihat dari p-value lebih kecil dari level of significant (à) $=5 \%$ yang ditentukan atau nilai t-hitung (pada kolom t) lebih besar dari t-tabel dihitung dari one-tailed à= 5\% df-k, pada kolom confident level $95 \%$ dan level of significant $(\grave{a})=5 \%$.

Hasil uji t dapat dilihat pada output Coefficients dari hasil regresi linear sederhana pada program SPSS yang didapatkan hasil sebagai berikut:

Tabel 3

Model Regresi

Coefficients $^{\mathrm{a}}$

\begin{tabular}{|c|c|c|c|c|c|}
\hline \multirow{2}{*}{ Model } & \multicolumn{2}{|c|}{ Unstandardized Coefficients } & Standardized & \multirow[t]{2}{*}{$\mathrm{T}$} & \multirow[t]{2}{*}{ Sig. } \\
\hline & $B$ & Std. Error & Beta & & \\
\hline (Constant) & 6,195 & 1,260 & & 4,918 & , 128 \\
\hline Likuiditas &,- 008 & ,018 &,- 397 &,- 432 & ,740 \\
\hline
\end{tabular}

a. Dependent Variable: Profitabilitas

Sumber: data diolah (output program SPSS 20)

Dari data di atas maka pada uji t (parsial) dapat dituliskan sebagai berikut:

Ho dapat diterima jika nilai $p$-value > level of significan, tingkat signifikansi yang digunakan adalah 0,05 ( $\alpha=5 \%)$. Dapat dilihat bahwa $p$-value > level of significan $(0,74>0,05)$ berarti $\mathrm{H} \alpha$ ditolak dan Ho diterima. Jadi dapat disimpulkan bahwa Likuiditas tidak berpengaruh terhadap profitabilitas.

\section{Koefisien Determinasi}




\section{Tabel 5}

Nilai koefisien determinasi

Model Summaryb

\begin{tabular}{|l|r|r|r|r|r|}
\hline Model & $\mathrm{R}$ & $\mathrm{R}$ Square & $\begin{array}{c}\text { Adjusted R } \\
\text { Square }\end{array}$ & $\begin{array}{c}\text { Std. Error of the } \\
\text { Estimate }\end{array}$ & Durbin-Watson \\
\hline 1 &, $397^{\mathrm{a}}$ &, 157 &,- 685 &, 40555 & 2,586 \\
\hline
\end{tabular}

a. Predictors: (Constant), Likuiditas

b. Dependent Variable: Profitabilitas

Sumber: data diolah (output program SPSS 20)

Berdasarkan pada Tabel 4.5 dapat diketahui bahwa nilai koefisien kolerasi (R) sebesar 0,397 dapat diartikan bahwa terdapat hubungan positif dan searah antara variabel $\mathrm{X}$ dengan variabel Y. Nilai R2 $=0,157$. Ini berarti, pengaruh variabel $\mathrm{X}$ (Likuiditas) terhadap variabel Y sebesar $15,7 \%$ dan pengaruh variabel lainnya sebesar $84,3 \%$ yang tidak dimasukkan dalam model penelitian ini.

\section{KESIMPULAN / CONCLUSION}

\section{Kesimpulan}

Berdasarkan hasil penelitian yang telah dilakukan pada PT PLN (Persero) Bulukumba Kabupaten Bulukumba tahun 2015-2017, maka dapat disimpulkan bahwa:

a. Rasio likuiditas menunjukkan kurang baik disebabkan dari tahun 2015 sampai tahun 2017 terjadi peningkatan hutang.

b. Rasio profitabilitas menunjukkan kondisi yang baik disebabkan secara konsisten mampu meningkatkan laba atau profit.

c. Hasil dari penelitian ini menunjukkan bahwa pada tahun 2015-2017, likuiditas memiliki pengaruh yang negatif terhadap profitabilitas return On Assets (ROA).

d. Current ratio tidak memiliki pengaruh yang signifikan terhadap profitabilitas return on assets (ROA).

\section{Saran}

Saran atas penerapan ipteks pengukuran kinerja keuangan PT. PLN (Persero) ULP Tanete ini adalah:

a. Hasil penelitian ini diharapkan bagi perusahaan untuk menjaga kelangsungan hidup dan kontinuitas perusahaan dengan upaya mengelola kebijaksanaan keuanganya dengan baik, di mana sebuah perusahaan dapat dikatakan mempunyai kinerja yang baik bilamana dalam kegiatan perusahaan tersebut mampu memenuhi kewajiban finansialnya dan sekaligus mampu menghasilkan keuntungan.

b. Melakukan analisis laporan keuangan secara rutin sehingga dapat mengetahui dan mengevaluasi kinerja perusahaan serta mampu mengoptimalkan harta perusahaan untuk memaksimalkan dalam perolehan pendapatan.

c. Penelitian ini masih memiliki keterbatasan, termasuk lingkup penelitian dan waktu penelitian dalam melaksanakan penelitian ini. Oleh sebab itu kritik dan saran dari setiap orang sangat di butuhkan dalam penelitian ini agar dapat mendekati standar poin yang diharapkan. 
d. Untuk Peneliti selanjutnya, penelitian dapat di lanjutkann dengan melakukan penelitian yang sama dengan cakupan penelitian yang lebih luas dan juga waktu yang lebih panjang sehingga dapat lebih menyempurnakan penelitian ini.

e. Menambah variabel independen sehingga dapat menyempurnakan variabel-variabel yang telah digunakan sebelumnya yang meneliti pengaruh likuiditas terhadap profitabilitas.

Peneliti merekomendasikan untuk melakukan penelitian tentang Analisis Pengaruh Tingkat

Likuiditas Terhadap Profitabilitas dengan mengambil sampel data yang lebih banyak.

\section{DAFTAR PUSTAKA / REFERENCES}

Alex S Nitisemito, (2010). Pembelanjaan Perusahaan. Edisi Keempat, Jakarta: Balai Aksara Saadya.

Kasmir dan Jakfar, (2012).Studi Kelayakan Bisnis, Edisi Revisi. Jakarta: Kencana.

Kasmir. (2014). Analisis Laporan Keuangan, Jakarta: PT. Raja Grafindo Persada.

Mamduh, M. H., \& Halim, A. (2003). Analisis Laporan Keuangan, YKPN, Yogyakarta.

Atmajaya, L. S. (2009). Manajemen Keuangan. Edisi Revisi, Yogyakarta: Andi

Napa J. Awat, (1999). Manajemen Keuangan Pendekatan Matematis, Jakarta: PT. Gramedia Pustaka,).

J. Fred Weston dan Copeland, (1997). Manajemen Keuangan. Jilid 2. Edisi Kesembilan, Jakarta: Binarupa Aksara.

Raharjaputra, H. S. (2009). Manajemen Keuangan dan Akuntansi. Jakarta: Salemba Empat.

Sugiyono. (2017). “Metode Penelitian Kuantitatif Kualitatif dan R\&D”, Bandung: Alfabeta. 